\title{
Consistent variation in individual migration strategies of brown skuas
}

\author{
Johannes Krietsch ${ }^{1}$, Steffen Hahn ${ }^{2}$, Matthias Kopp ${ }^{1}$, Richard A. Phillips ${ }^{3}$, \\ Hans-Ulrich Peter ${ }^{1}$, Simeon Lisovski ${ }^{4,5, *}$ \\ ${ }^{1}$ Friedrich Schiller University Jena, Institute of Ecology, Polar and Bird Ecology Group, 07743 Jena, Germany \\ ${ }^{2}$ Swiss Ornithological Institute, Department of Bird Migration, 6204 Sempach, Switzerland \\ ${ }^{3}$ British Antarctic Survey, Natural Environment Research Council, Cambridge CB3 0ET, UK \\ ${ }^{4}$ Deakin University, School of Life and Environmental Sciences, Centre for Integrative Ecology, Geelong, Victoria 3220, \\ Australia \\ ${ }^{5}$ University of California, Department of Neurobiology, Physiology, and Behavior, One Shields Avenue, Davis, \\ California 95616, USA
}

\begin{abstract}
Seabirds show remarkable variability in migration strategies among individuals and populations. In this study, we analysed 47 migrations of 28 brown skuas Catharacta antarctica lonnbergi breeding on King George Island in the Maritime Antarctic. Brown skuas from this population used a large area during the non-breeding period north of $55^{\circ} \mathrm{S}$, including parts of the Patagonian Shelf, Argentine Basin and South Brazil Shelf, areas which are characterised by high levels of marine productivity. However, individual birds utilised only a subset of these areas, adopting 1 of 4 distinct migration strategies to which they were highly faithful between years, and showed high repeatability in departure and arrival dates at the breeding ground. Although they spent the majority of the non-breeding season within a particular region, almost all individuals used the same area in the late winter, exploiting its seasonal peak in productivity. Overall, these results indicate consistent individual variation in migration strategies that may reflect a combination of genetic control and individual experience, but with considerable flexibility to shift distribution in response to prevailing environmental conditions.
\end{abstract}

KEY WORDS: Catharacta antarctica lonnbergi · Seabird ecology · Light-level geolocation · Non-breeding distribution - Individual consistency - Ocean primary productivity · Migratory connectivity

\section{INTRODUCTION}

Migratory seabirds spend much of the year at sea, far from their breeding grounds, yet have traditionally been studied much more intensively during the breeding than the non-breeding season. However, a growing body of literature demonstrates that these temporally and often geographically distinct periods of the annual cycle are inextricably linked (Harrison et al. 2011). This bias in research towards studies focussing on the breeding season limits our under-

${ }^{*}$ Corresponding author: simeon.lisovski@gmail.com

${ }^{\S}$ Advance View was available online January 5, 2017 standing of the ecology of many species, and how individuals and populations are affected by major stressors such as rapid environmental change (Ådahl et al. 2006, Small-Lorenz et al. 2013).

Recent advances in tracking technologies (Bridge et al. 2011) have facilitated numerous studies involving tracking individuals over an extended period of time. This development allows investigation of spatiotemporal consistency in migration strategies within and among individuals and populations (e.g. Phillips et al. 2005, Dias et al. 2011). Although the Attribution Licence. Use, distribution and reproduction are un restricted. Authors and original publication must be credited. 
general direction of migration seems to be largely determined by genetics or, in some species, cultural inheritance (Berthold 2001, Mueller et al. 2013), movement patterns of individuals and populations also respond to factors such as food availability (Shealer 2002, Karnovsky et al. 2003). However, prey availability in marine ecosystems is generally characterised by varying degrees of temporal and spatial predictability (Weimerskirch 2007) and hence it cannot be assumed that all areas will be favourable for a particular species in every year. This could ultimately lead to variation in individual migration patterns of seabirds at some spatial scale across years. Indeed, although most species show high individual consistency in non-breeding destinations at a large spatial scale (Phillips et al. 2005, Fifield et al. 2014, Müller et al. 2014), there are exceptions; in addition, in almost all species there is extensive variation both among and within individuals in routes, use of staging areas and timing (Quillfeldt et al. 2010, Dias et al. 2011, McFarlane Tranquilla et al. 2014).

In this study, we analysed the migration strategies of individual brown skuas Catharacta antarctica lonnbergi breeding on the South Shetland Islands in the Maritime Antarctic. Migration routes and nonbreeding areas were derived using light-level geolocators (also termed global location sensors or GLS loggers), and our dataset included repeated tracks from individuals over 2 to 3 yr. Brown skuas are longlived and highly opportunistic top predators, with a circumpolar breeding distribution on subantarctic islands and the Antarctic Peninsula (Furness 1987, Ritz et al. 2008). To date, the only detailed distribution data available for brown skuas during the nonbreeding period are for birds from the population at South Georgia, migrating to waters between the northern extent of the Subtropical Front and the southern boundary of the Antarctic Circumpolar Current, and between the Argentine and Agulhas (Phillips et al. 2007, Carneiro et al. 2016). In contrast, the limited data for the closely related Falkland skuas C. a. antarctica, tracked in different years, suggest a non-breeding distribution mainly in subantarctic waters around the central Patagonian shelfbreak (Phillips et al. 2007).

Given the lack of knowledge of the non-breeding ranges of brown skuas from the South Shetland Islands, the adjacent southern population, and the inclusion in our dataset of repeated migration tracks from the same individuals in multiple years, the aims of the study were 2 -fold. Firstly, we aimed to reveal the spatiotemporal non-breeding distribution of the tracked population, the degree of variation among individuals, and the effects of sex, year and previous breeding performance. Secondly, we aimed to quantify individual consistency in annual migration strategies. In addition, we used activity (immersion) data recorded by the loggers, and remotely sensed data on net primary production to examine the correlation between this proxy for food availability, and the movement and activity patterns of individual birds.

\section{MATERIALS AND METHODS}

\section{Logger deployment and retrieval}

Fieldwork was carried out on adult brown skuas at King George Island (Fildes Peninsula, 62 ${ }^{\circ} 19^{\prime} \mathrm{S}$, $58^{\circ} 95^{\prime} \mathrm{W}$ ) in the Maritime Antarctic. A total of 46 geolocator-immersion loggers were deployed on 33 individuals (which at the time were of unknown sex) over the course of 3 breeding seasons (2006/2007 to 2008/2009). Three types of loggers (manufactured by the British Antarctic Survey) were used in this study: MK5 $(\mathrm{n}=20)$, MK9 $(\mathrm{n}=22)$ and MK15 $(\mathrm{n}=4)$. Total weights were $6.4,5.3$ and $5.3 \mathrm{~g}$, respectively, which included the device, aluminium ring and cable ties used for attachment (together with metal ring of $3 \mathrm{~g}$ used for identification, corresponding to $\sim 0.6 \%$ of the mean body mass). Besides recording light intensity over time, all loggers tested for saltwater immersion every $3 \mathrm{~s}$ and stored the sum of positive tests at 10 min intervals, resulting in values between 0 (entirely dry) and 200 (entirely wet). Birds were recaptured in the subsequent season, and in 11 cases the loggers were replaced by a new device; these devices and others from the initial deployments were retrieved in the third season. A blood sample was taken from each bird $(\sim 50 \mu \mathrm{l})$, stored at $-20^{\circ} \mathrm{C}$, and later used to determine sex from DNA (Fridolfsson \& Ellegren 1999). All individuals were monitored regularly in the pre- and post-migratory season (from early December to March) to determine breeding status and performance (i.e. success vs. failure).

\section{Departure and arrival date}

Since brown skuas switch from a predominantly terrestrial lifestyle to almost exclusively marine habitat after leaving the breeding site (Phillips et al. 2007), departure and arrival dates at King George Island were identified by visual inspection of immersion data. For individuals lacking immersion data because of logger malfunction, these dates were 
identified from the length and frequency of shading of the light sensor during daylight, which is substantially higher when skuas spend time sitting on land at the breeding ground. The duration of the non-breeding period was based on departure and arrival dates. Some individuals also went on a pre-laying exodus within a few weeks of first return to the colony.

\section{Movement pathway analysis}

Positions during the non-breeding season were estimated from raw light intensity data using the threshold method (Lisovski et al. 2012). Twilight events (i.e. sunrise and sunset transitions) were defined using the R package 'BAStag' (Wotherspoon et al. 2013a) based on a light intensity threshold of 2.5. Twilight times that were clearly suspect because of shading of the sensor (i.e. $>30$ min difference from the previous or subsequent day) were discarded, and the time interpolated with respect to the surrounding twilights. This approach was applied to between 5 and $10 \%$ of all twilights during the annual migration of each individual. Locations from the breeding period were excluded from subsequent analyses. We used a Bayesian framework to refine the initial, rough positions estimated from the threshold method and to derive uncertainty estimates. The R package 'SGAT' (Wotherspoon et al. 2013b) uses Markov Chain Monte Carlo (MCMC) simulations allowing the incorporation of a spatial probability mask, prior definition of the error distribution of twilight events (twilight model) and a flight speed distribution to refine location estimates (for detailed information see Sumner et al. 2009 and Lisovski et al. 2016). The twilight model should reflect the expected error in detecting the real time of sunrise and sunset. Since brown skuas spend a substantial amount of time sitting at the breeding site, which obscures the light sensor, we could not use twilight times from a known location (i.e. breeding site) to parameterise the twilight model. We therefore used a rather conservative prior (log-normal distribution: meanlog $=2$, sdlog $=$ 1.2) describing a large variation in the discrepancy between the real and recorded twilight events. The movement behaviour was modelled assuming that over the course of the non-breeding periods, brown skuas are sedentary for the majority of the time (high likelihood of very slow movement speeds) while allowing for occasional fast movements $\left(\sim 80 \mathrm{~km} \mathrm{~h}^{-1}\right)$ during migration (gamma distribution; shape $=0.7$, scale $=0.05)$. The spatial mask was based on the assumption that the tracked individuals avoid land
(10 times lower probability of occurrence on land compared to sea) and that the spatial range was between 10 and $70^{\circ} \mathrm{S}$, and 85 and $20^{\circ} \mathrm{W}$ (based on locations derived using the threshold method).

The threshold method requires a zenith angle to estimate locations, which is usually derived using light intensity recordings from tracked animals of known distributions, or fixed loggers. As these data were unreliable or unavailable for this study, we used an alternative approach, the 'Hill-Ekstrom calibration' (see Lisovski et al. 2012) to estimate the right zenith angle for each annual migration track. First, for all tracks, initial locations were estimated using a zenith angle of $95^{\circ}$ (i.e. sun elevation angle of $-5^{\circ}$ ). Next, using the initial locations, a set of MCMC simulations (drawing 2400 samples) was performed using a range of zenith angles between 94 and $96^{\circ}$. The median path for each zenith angle and a total of 2400 chains were then calculated. We then choose the zenith angle that minimised the variance in latitude estimates during periods when the tracked birds were largely sedentary within their non-breeding range. The derived zenith angles varied between individual tracks, and ranged from 94.5 to $95.7^{\circ}$.

Using those zenith angles, a complete MCMC simulation was performed on each individual annual track. An initial 2000 samples were drawn and discarded to allow for both burn-in and tuning of the proposal distribution, i.e. to find an initial path that matches the model assumptions. A final 4000 samples were than drawn to describe the posterior distribution. Convergence of chains, i.e. whether 2 independent simulations produce the same result, was evaluated by visual inspection by comparing the median tracks. The final run provided 4000 chains of possible migration pathways that satisfied the defined sunrise and sunset times, their error distribution, the movement behaviour and the spatial mask. The set of chains were used to generate time-spent maps illustrating the relative probability distribution of an individual at a given time or period, and to calculate most likely tracks.

\section{Activity analysis}

Saltwater immersion data recorded by the logger were used to determine activity patterns of brown skuas using the web-based program Actave.net (Mattern et al. 2015). Values of 0 (entirely dry), 1 to 199, and 200 (entirely wet) in each $10 \mathrm{~min}$ period were categorised as either 'flight' (as skuas remain at sea during the non-breeding period), 'foraging' or 
'sitting on water', respectively, assigned to daylight or darkness periods based on nautical twilight hours and summarised accordingly (see Mattern et al. 2015). Although some intermediate values (from 1 to 199) will reflect non-foraging behaviour, in general this categorisation is assumed to provide a reasonable indication of foraging activity among seabirds (McKnight et al. 2011, Cherel et al. 2016).

\section{Spatial data analysis}

We used R (R Core Team 2015) to manipulate and analyse all data. A Lambert Azimuthal Equal Area projection was used for all spatial analyses and mapping. Due to the large error distribution of the twilight times, the MCMC simulation did not perform well in correcting location estimates during the period of the equinox (1 March to 22 April, and 22 August to 9 October), and these locations were therefore excluded from all analyses.

Movement patterns within the non-breeding range were analysed in the context of the Marine Ecoregions of the World (MEOW), biogeographic areas of relatively homogenous and distinct species composition (for details, see Spalding et al. 2007). However, MEOW only characterises costal and shelf areas, and we therefore added the 'Argentine Basin' to be able to categorise the entire non-breeding range of the tracked brown skuas. For each position on the individual median tracks (i.e. the most likely track) we extracted the corresponding MEOW. To quantify the relative use of the various MEOW by each individual, the proportions of time spent inside each region between 22 April and 22 August was calculated. These proportions were used to group individual tracks based on the similarity in the use of each MEOW, using a cluster analysis with Euclidean distance (R package 'vegan'; Oksanen et al. 2015). To exclude individual effects, the analysis was initially performed using the first track of each individual only. Subsequently, and to evaluate the robustness of the groups, all 47 annual tracks were analysed together followed by a repeated analysis using Ward's method (Oksanen et al. 2015).

The relative probability distributions (i.e. timespent maps) between 22 April and 22 August were used to investigate the spatial overlap of movement paths among and within individuals. Each individual relative probability distribution $\left(D_{X Y}\right)$ corresponded to a raster with $X Y$ grid cells and a resolution of 39.3 $\times 55.6 \mathrm{~km}$. The values were normalised such that $\Sigma_{X} \Sigma_{Y}$ $D_{X Y}=1$. The degree of overlap $(O)$ between 2 tracks
( $a$ and $b$ ) was defined as the sum of the minimal value over all shared (overlapping) grid cells according to:

$$
O_{a b}=\Sigma_{X} \Sigma_{Y} \min \left(D_{X Y a} \mid D_{X Y b}\right)
$$

This calculation results in 0 if the 2 tracks share no common grid cell and in 1 if the 2 probability distributions were $100 \%$ identical. All combinations of the 47 annual tracks were calculated. The resulting degrees of overlap were arcsine square root transformed to meet statistical assumptions.

To reveal temporal trends in marine productivity (as a proxy of the seasonal dynamics of food availability at a mesoscale level), and to test for relationships with individual distributions, timing of movements and activity patterns of the tracked skuas, we downloaded net primary production data (NPP) from www.science.oregonstate.edu/ocean.productivity/ index.php (accessed 5 August 2014), in 8 d intervals and a resolution of $0.17^{\circ}$. Individual brown skua probability distributions were pooled into $8 \mathrm{~d}$ intervals to match NPP data format and normalised such that $\Sigma_{X} \Sigma_{Y} D_{X Y}=1$. If the matched NPP data had missing values corresponding to $>50 \%$ of the probability distribution, the $8 \mathrm{~d}$ interval was excluded from the analysis. The relative probability distributions were then used to weight the NPP data of each corresponding grid cell according to:

$$
\mathrm{NPP}_{\text {sum }}=\Sigma_{X} \Sigma_{Y}\left(D_{X Y} \times \mathrm{NPP}_{X Y}\right)
$$

\section{Statistical analysis}

We used linear mixed-effect models ( $\mathrm{R}$ package 'Ime4'; Bates et al. 2014) to quantify the effects of sex, breeding performance (i.e. successful [at least one chick fledged] or unsuccessful in the current season) and migration strategy on the subsequent timing of migration (departure date, arrival date, duration) and individual activity patterns (foraging activity, number of dry bouts and duration of dry bouts). To avoid pseudoreplication, individual identity was included as a random intercept. Two individuals with behaviours very different to the others were excluded from specific analysis: ID 108276 departed exceptionally early (15 January) in 2008, and was excluded from the analysis of departure date and duration, and ID 139514 spend several (dry) nights on a vessel or on land, biasing the activity data. To correct for temporal autocorrelation in the model testing for an effect of prey predictability (i.e. NPP) on activity pattern, the random effect was specified as days since the start of the non-breeding season each year (hereafter 
'day of the year') nested within individuals. p-values were calculated using the 'ImerTest' package (Kuznetsova et al. 2015). A linear mixed-effect model with the binary fixed factors ( 1 as 'same' and 0 as 'different') 'same sex', 'same year', 'same breeding performance' and 'same individual', and the random factor 'individual' was used to test for differences among and within groups in the spatial overlaps of the probability distributions.

Individual repeatability, i.e. the intraclass correlation coefficient, which allows the quantification of variance among and within individuals (Lessells \& Boag 1987), was calculated for timing of migration and mean activity metrics obtained in different years. Linear mixed-effect models with individual as random effect and year as fixed factor were fitted for each sex. Due to the small sample size, models fitted to the activity metrics were not separated by sex, and sex was instead included as a fixed factor. The adjusted repeatability value, corresponding confidence interval and $\mathrm{p}$-value were calculated using the R package 'rptR' (Nakagawa \& Schielzeth 2010).

\section{RESULTS}

\section{Logger retrieval details}

DNA sexing revealed that the loggers were deployed on 33 females and 13 males. A total of 42 (91\%; 31 females, 11 males) of the loggers were retrieved, which provided data on 47 annual tracks of 28 individuals ( 20 females, 8 males) between 2007 and 2010, including migrations of the same individuals over $2(n=13)$ or $3(n=3)$ non-breeding seasons. Additionally, saltwater immersion data were recorded for 35 of the 47 annual tracks.

\section{Spatiotemporal distribution}

During the non-breeding period, the tracked brown skuas were widely distributed north of their breeding sites, over parts of the Patagonian Shelf, the Argentine Basin and, to a lesser extent, the Southern Brazil Shelf (Fig. 1a). This distribution includes regions with heterogeneous levels of productivity: subantarctic, mixed subantarctic-subtropical and subtropical, and open shelf waters. The core area of the distribution overlapped with the Patagonian shelfbreak front, the confluence zone of the Falkland and Brazil currents, and offshore of the Rio de la Plata estuary.
Single individuals used distinct portions of the entire area, revealing characteristic spatiotemporal patterns (Fig. 2). Based on the time spent in each MEOW, the annual tracks could be grouped in $4 \mathrm{mi}-$ gration strategies. Applying cluster analyses with different linking methods on all annual tracks, or only
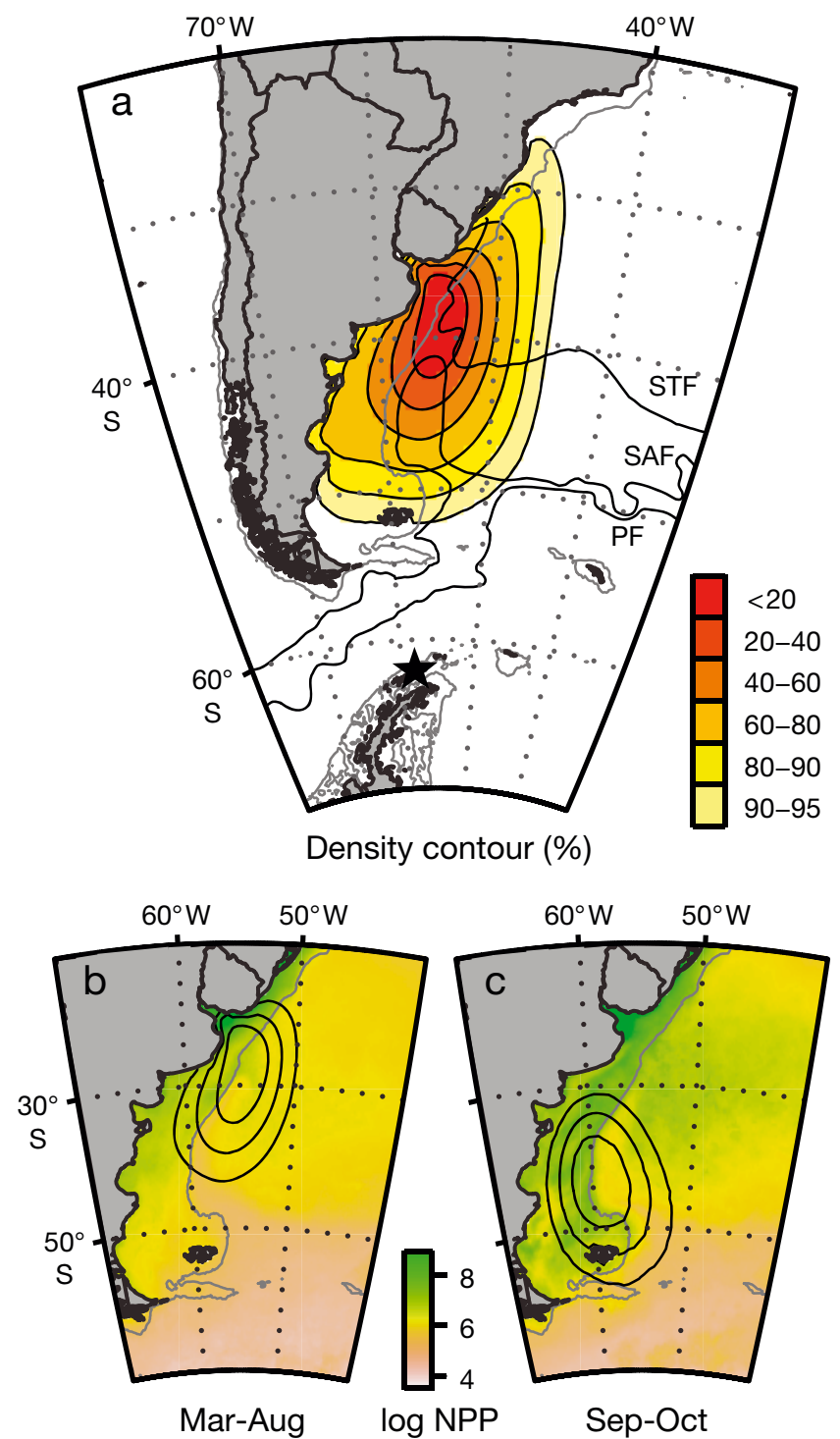

Fig. 1. (a) Density distribution of 28 brown skuas Catharacta antarctica lonnbergi from King George Island (black star) during the non-breeding period from 2007 to 2010. Black lines: approximate locations of the Subtropical Front (STF), Subantarctic Front (SAF) and Polar Front (PF) based on Orsi et al. (1995); grey line: $500 \mathrm{~m}$ bathymetric contour, indicating the Patagonian shelf-break. (b) Mean net primary production (NPP; in $\mathrm{mg} \mathrm{C} \mathrm{m}^{-2} \mathrm{~d}^{-1}$ ) between the mean departure date of brown skuas (17 March) and August from 2007 to 2010, and (c) NPP (in $\mathrm{mg} \mathrm{C} \mathrm{m}^{-2} \mathrm{~d}^{-1}$ ) between September and the mean arrival date of brown skuas (31 October) from 2007 to 2010 , both overlaid by the density distribution (contour lines: 20,40 , and $60 \%$ ) of brown skuas in the same period 
a

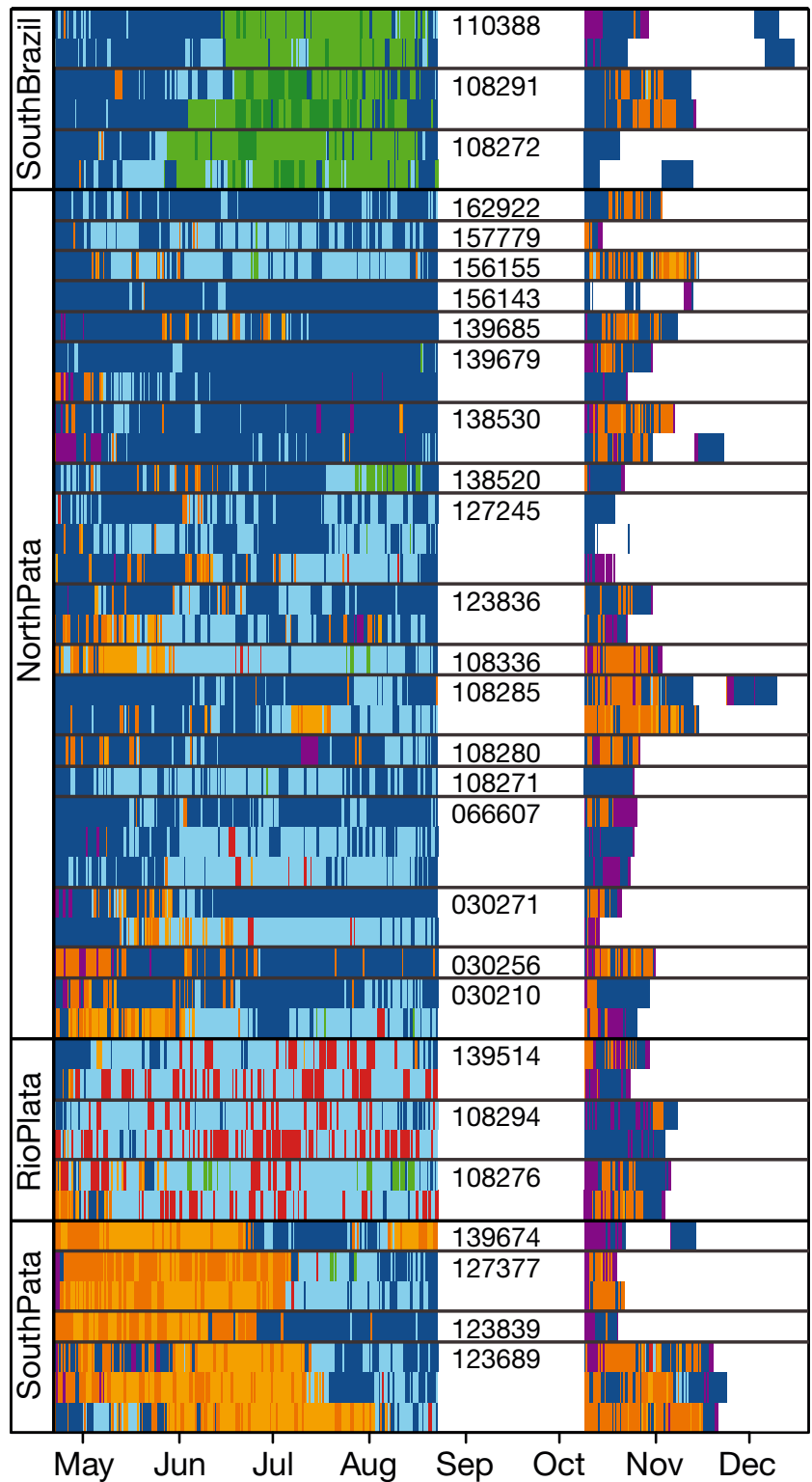

the first from each individual, distinguished up to 5 groups. However, 3 groups were always identified as clearly distinct, independent of the methods and data background: (1) a group of individuals that utilised the 'Argentine Basin' at the end of April and in May, and, for a shorter period, the 'UruguayBuenos Aires Shelf', which corresponds to the use of the Brazil-Falklands confluence. Subsequently, at the beginning of June, these birds moved to the Southern Brazil Shelf, where they primarily utilised the 'Rio Grande' and partly 'Southeastern Brazil'. These annual tracks were assigned to the migration strategy 'South Brazil Shelf' (SouthBrazil), and consisted of 3 individuals $(11 \%)$. (2) Individuals that mainly used the 'Uruguay-Buenos Aires Shelf' between April and b
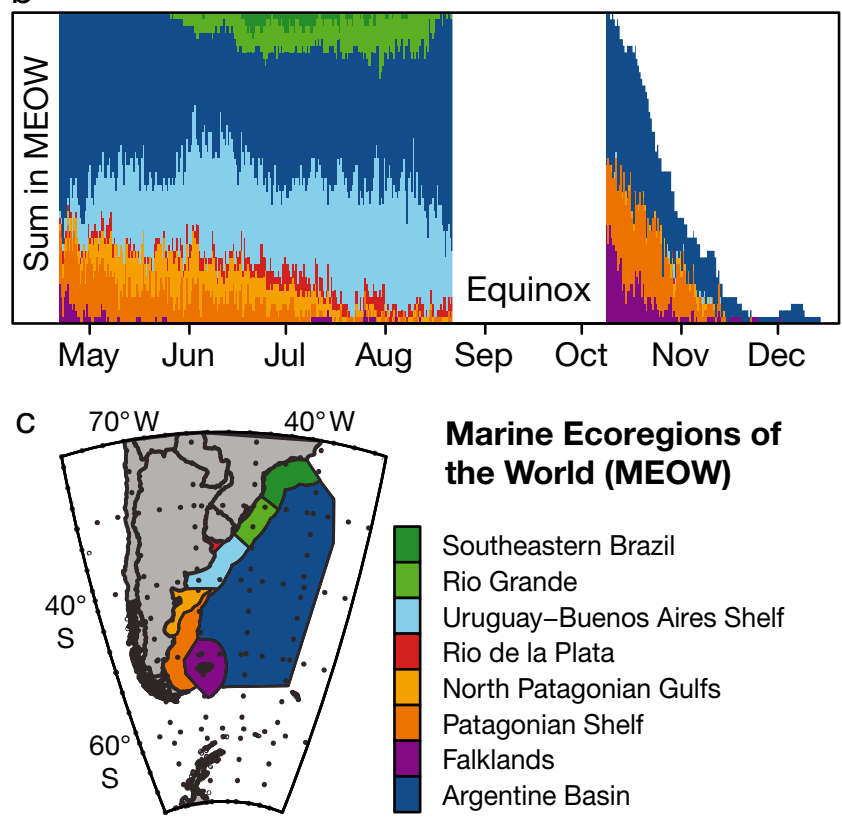

\section{Marine Ecoregions of the World (MEOW)}

Southeastern Brazil

Rio Grande

Uruguay-Buenos Aires Shelf

Rio de la Plata

North Patagonian Gulfs

Patagonian Shelf

Falklands

Argentine Basin

Fig. 2. (a) Location of the most likely position within the Marine Ecoregions of the World (MEOW; following Spalding et al. 2007, supplemented with the 'Argentine Basin' to cover the whole non-breeding range) of 28 brown skuas Catharacta antarctica lonnbergi from King George Island during the non-breeding period. Brown skuas were tracked in $4 \mathrm{yr}$ (2007 to 2010); 16 individuals in 2 or 3 consecutive years. Individuals are grouped by 4 migration strategies based on cluster analysis, including the proportions of annual tracks in the MEOW. (b) Proportional distribution of all tracks within the MEOW. Note the use of different MEOW between April and August, whereas almost all individuals used the same region in October and November. No reliable positions could be calculated around the equinoxes (1 March to 22 April, and 22 August to 9 October). Migration strategies: 'South Brazil Shelf' (SouthBrazil), 'North Patagonian Shelf/Argentine Basin' (NorthPata), 'Rio de la Plata' (RioPlata), 'South Patagonian Shelf' (SouthPata). (c) Extent of the MEOW used by the tracked skuas

September as well as the 'Rio de la Plata'. These tracks were assigned to the migration strategy 'Rio de la Plata' (RioPlata), including tracks of 3 individuals $(11 \%)$. (3) Individuals grouped across the southern Patagonian Shelf, e.g. the 'North Patagonian Gulfs' and 'Patagonian Shelf', between April and July to August. These tracks were assigned to the migration strategy 'South Patagonian Shelf' (SouthPata) and consisted of 4 individuals (14\%). The cluster analysis could not clearly separate the remaining 2 groups, and assignment of tracks was dependent on method and data background. (4) Individuals that mainly used the 'Argentine Basin' and the 'Uruguay-Buenos Aires Shelf'. Most of these birds moved frequently between these 2 major regions and some were also distributed 
partly over the southern Patagonian Shelf. These tracks of 18 individuals (64\%) were assigned to migration strategy 'North Patagonian Shelf/Argentine Basin' (NorthPata).

In October, the differences between individual strategies diminished (Fig. 2b), and almost all skuas moved into a highly seasonal and productive area: the transition zone between the 'Argentine Basin', the 'Patagonian Shelf' and the 'Falklands' (Fig. 1c). However, 3 individuals (IDs 127245, 108272 and 156143) did not use this area during this period, but rather were distributed east from the Falkland Islands over mixed water masses of the Antarctic Polar Front and the Subantarctic Front. One other individual (ID 156143) travelled as far east as the waters north of South Georgia.

On 9 occasions, 8 individuals (5 females, 3 males) performed a pre-laying exodus. These birds departed from King George Island after a median of $6 \mathrm{~d}$ (min. $=1 \mathrm{~d}$, max. $=36 \mathrm{~d})$ and their first arrival dates were on average $1 \mathrm{wk}$ before the arrival of birds that did not make a pre-breeding exodus. Seven individuals flew back to the north or east of the Falkland Islands, whereas the others remained in the proximity of King George Island or performed an $8 \mathrm{~d}$ trip to the Drake Passage.

The degree of overlap of the probability distributions was significantly larger $(22 \pm 0.3 \% \mathrm{SE}, \mathrm{p}<0.001)$ within individuals than among individuals (Fig. 3). Only 1 individual (ID 139679) showed an overlap of just $44 \%$, whereas the within-individual overlap for all the other tracked skuas was 60 to $95 \%$. This significant overlap in movement paths was reflected in the very high consistency within individuals with respect to their migration strategy (Fig. 2). This was higher in individuals using 'South Patagonian Shelf', 'Rio de la Plata' and 'South Brazil Shelf' than in individuals that adopted the 'North Patagonian Shelf/Argentine Basin' strategy. There was no significant effect of sex $(1.6 \pm$ $1.0 \% \mathrm{SE}, \mathrm{p}=0.117)$, year $(0.3 \pm 1.0 \% \mathrm{SE}, \mathrm{p}=0.796)$ or previous breeding performance $(0.4 \pm 1.0 \% \mathrm{SE}, \mathrm{p}=$ 0.691 ) on the distribution of the tracked birds.

\section{Timing of migration}

The mean departure date from King George Island was 17 March $( \pm 12$ d SD; 25 February to 13 April, $\mathrm{n}=$ 28). Females departed around 2 to 3 wk earlier than males $(17.38 \pm 2.75 \mathrm{~d} \mathrm{SE}, t=6.32, \mathrm{p}<0.001$; Fig. $4 \mathrm{a})$. 'SouthPata' individuals departed significantly earlier than 'NorthPata' $(17.7 \pm 3.47 \mathrm{~d} \mathrm{SE}, t=5.08, \mathrm{p}<0.001)$, 'RioPlata' (11.0 $\pm 4.96 \mathrm{~d} \mathrm{SE}, t=2.22, \mathrm{p}=0.03)$ and

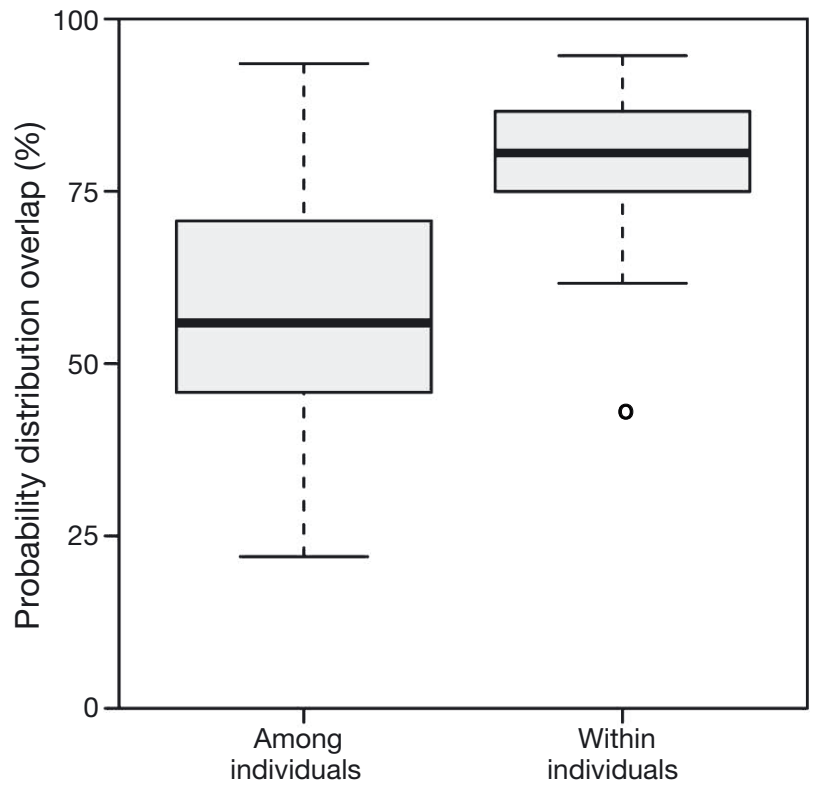

Fig. 3. Overlap among and within individual probability distributions of 28 brown skuas Catharacta antarctica lonnbergi from King George Island during the non-breeding periods from 2007 to 2010, including annual migrations of the same individuals over $2(n=13)$ or $3(n=3)$ yr. Line: median; box: 25 th -75 th percentiles; whiskers: 5 th -95 th percentiles; circles: outliers
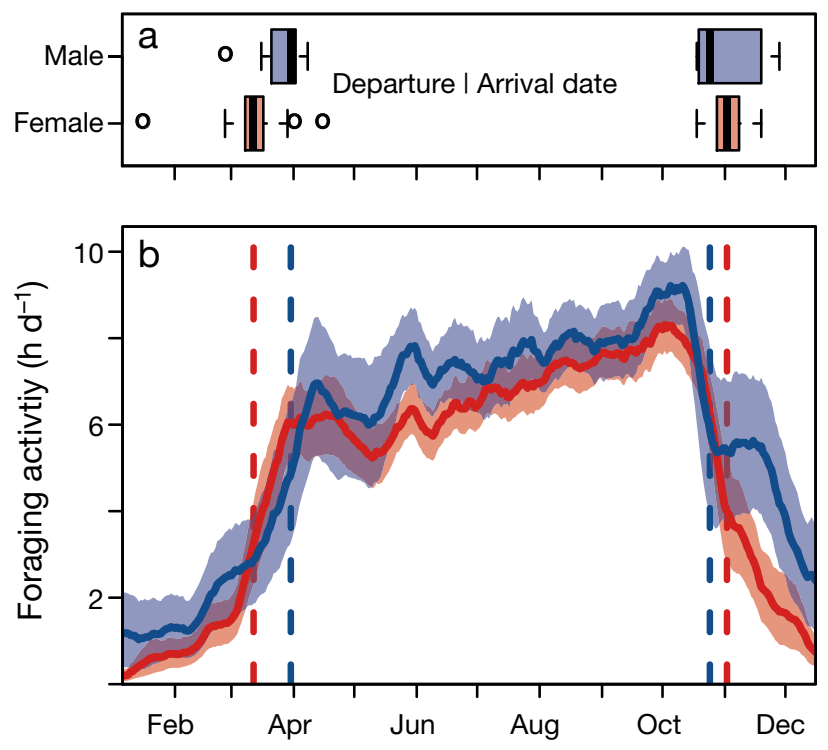

Fig. 4. (a) Departure and return dates of brown skuas Catharacta antarctica lonnbergi (20 females, 8 males) from King George Island during 2007 to 2010. Boxplot limits as in Fig. 3. (b) Marine foraging activity (20 d moving average and $95 \%$ CI) of 16 female (red) and 7 male (blue) brown skuas, throughout the years 2007 to 2010. Foraging activity was approximated by saltwater immersion data with intermediate (wet and dry) 10 min intervals. Note that brown skuas fed mainly on terrestrial prey during the breeding season and switched to a pelagic distribution after they left the breeding site. Dashed lines: median departure and return dates 
'SouthBrazil' individuals $(11.8 \pm 4.50 \mathrm{~d}$ SE, $t=2.6, \mathrm{p}=$ 0.01 ). Besides the significant differences between these particular strategies, departure date was not influenced by previous breeding performance (1 or 2 chicks fledged vs. unsuccessful; $3.41 \pm 2.39 \mathrm{~d} \mathrm{SE}, t=$ $1.42, \mathrm{p}=0.16)$ or year $(-0.61 \pm 1.21 \mathrm{~d} \mathrm{SE}, t=0.5, \mathrm{p}=$ 0.61 ). The repeatability value of the departure date was moderate in both sexes (Table 1).

Brown skuas returned to King George Island around 31 October $( \pm 10 \mathrm{~d} ; 17$ October to 23 November, $\mathrm{n}=28$ ). The arrival date did not differ significantly between sexes $(1.46 \pm 4.30 \mathrm{~d} \mathrm{SE}, t=0.34, \mathrm{p}=0.73)$, but was highly repeatable at the individual level (Table 1), and there were significant differences between years (2007-2010: $2.07 \pm 0.80 \mathrm{~d} \mathrm{SE}, t=2.57, \mathrm{p}=0.016)$.

The mean $( \pm \mathrm{SD})$ duration of the non-breeding period was $228 \mathrm{~d}( \pm 17 \mathrm{~d} ; 197$ to $272 \mathrm{~d}, \mathrm{n}=28)$, and was highly repeatable within individuals (Table 1). Males spent less time away from the breeding site than females $(18.37 \pm 5.21 \mathrm{~d}, t=3.52, \mathrm{p}=0.001)$ independent off year $(2.53 \pm 1.7 \mathrm{~d}, t=1.48, \mathrm{p}=0.14)$ and breeding performance $(6.04 \pm 3.7 \mathrm{~d}, t=1.62, \mathrm{p}=$ 0.11). Additionally, 'SouthPata' individuals had a significantly shorter non-breeding period $(20.2 \pm 6.68 \mathrm{~d}$, $\mathrm{p}=0.006$ ) than 'NorthPata' individuals.

\section{Activity patterns}

During the non-breeding period, tracked brown skuas spent a large proportion of the day sitting on water (females: $57 \pm 4.40 \% \mathrm{SD}, \mathrm{n}=16$; males: $55.38 \pm$ $6.08 \% \mathrm{SD}, \mathrm{n}=7$ ) and a much smaller proportion in flight (females: $14.71 \pm 3.45 \% \mathrm{SD}, \mathrm{n}=16$; males: $12.46 \pm 4.10 \% \mathrm{SD}, \mathrm{n}=7$ ). The length of time categorised as foraging was significantly higher in males than females $(0.93 \pm 0.30 \mathrm{~h} \mathrm{SE}, t=3.06, \mathrm{p}=0.006$; Table 1), and was concentrated mainly during the day (females: $67.21 \pm 8.08 \% \mathrm{SD}, \mathrm{n}=16$; males: 69.45 $\pm 8.45 \% \mathrm{SD}, \mathrm{n}=7$ ) rather than at night (females: $22.34 \pm 5.98 \% \mathrm{SD}, \mathrm{n}=16$; males: $21.37 \pm 4.70 \% \mathrm{SD}$, $\mathrm{n}=7$ ). Foraging activity differed significantly between years $(-0.20 \pm 0.07 \mathrm{~h} \mathrm{SE}, t=2.61, \mathrm{p}=0.009)$ and over the non-breeding period $(0.07 \pm 0.009 \mathrm{~h} \mathrm{SE}$, $t=8.06, \mathrm{p}<0.001)$, but there was no significant repeatability within individuals (Table 1 ). Within the non-breeding period, the foraging activity peaked in early October (Fig. 4b), before the brown skuas returned to King George Island.

The number of flight bouts per day did not differ significantly between males $(4.16 \pm 1.02 \mathrm{SD})$ and females ( $3.86 \pm 0.65 \mathrm{SD})(0.35 \pm 0.24 \mathrm{SE}, t=1.44, \mathrm{p}=$ $0.16)$. Day of the year had a significant effect $(0.16 \pm$ $0.01 \mathrm{~h} \mathrm{SE}, t=9.02, \mathrm{p}<0.001$ ) on the number of flight bouts, but there was no effect of year $(-0.07 \pm 0.08 \mathrm{~h}$ $\mathrm{SE}, t=0.83, \mathrm{p}=0.40)$. However, the number of flight bouts was not repeatable within individuals (Table 1). In contrast, there was a significant effect of sex (females: $63.53 \pm 19.04 \mathrm{~min}$ SD, males: $45.97 \pm 8.45 \mathrm{~min}$

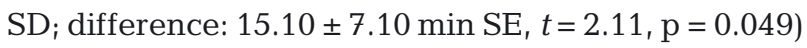
and year $(-5.81 \pm 2.16 \mathrm{~min} \mathrm{SE}, t=2.68, \mathrm{p}=0.009)$ on the duration of flight bouts, which was independent of

Table 1. Migration characteristics (mean departure date, arrival date and duration) and activity patterns (foraging activity, number and duration of flight bouts) of brown skuas Catharacta antarctica lonnbergi during the non-breeding periods from 2007 to 2010, and their individual repeatability (R, lower and upper $95 \%$ CIs and p-values). Mean values were calculated using only data from the first migration track from every individual $\left(\mathrm{N}_{\text {ind }}\right)$ and repeatability values, using repeated migrations $\left(\mathrm{N}_{\text {rep}}\right)$ over 2 or $3 \mathrm{yr}$

\begin{tabular}{|c|c|c|c|c|c|c|c|c|}
\hline & Sex & $\mathrm{N}_{\text {ind }}$ & Value \pm SD & $\mathrm{N}_{\text {ind }} / \mathrm{N}_{\text {rep }}$ & $\mathrm{R}$ & Lower CI & Upper CI & $\mathrm{p}$-value \\
\hline \multirow{2}{*}{$\begin{array}{l}\text { Departure date } \\
\text { from breeding site }\end{array}$} & Female & 20 & $13 \mathrm{March} \pm 10 \mathrm{~d}$ & $11 / 23$ & 0.477 & 0.009 & 0.821 & 0.002 \\
\hline & Male & 8 & 26 March $\pm 13 d$ & $4 / 10$ & 0.490 & 0.035 & 0.747 & $<0.001$ \\
\hline \multirow{2}{*}{$\begin{array}{c}\text { Arrival date at } \\
\text { breeding site }\end{array}$} & Female & 20 & 31 October $\pm 8 \mathrm{~d}$ & $12 / 25$ & 0.871 & 0.729 & 0.995 & $<0.001$ \\
\hline & Male & 8 & 30 October $\pm 15 \mathrm{~d}$ & $4 / 10$ & 0.972 & 0.939 & 0.991 & $<0.001$ \\
\hline \multirow{2}{*}{$\begin{array}{l}\text { Duration of the non- } \\
\text { breeding period }\end{array}$} & Female & 20 & $232 \pm 12 \mathrm{~d}$ & $12 / 25$ & 0.814 & 0.590 & 0.937 & $<0.001$ \\
\hline & Male & 8 & $218 \pm 24 \mathrm{~d}$ & $4 / 10$ & 0.859 & 0.542 & 0.974 & $<0.001$ \\
\hline \multirow[t]{2}{*}{$\begin{array}{l}\text { Daily foraging } \\
\text { time in } \mathrm{h} \mathrm{d}^{-1}(\%)\end{array}$} & Female & 16 & $\begin{array}{c}6.72 \pm 0.75 \\
(28.00 \pm 3.14)\end{array}$ & $7 / 16$ & 0.623 & 0.080 & 0.895 & 0.066 \\
\hline & Male & 7 & $\begin{array}{c}7.71 \pm 0.80 \\
(32.16 \pm 3.34)\end{array}$ & & & & & \\
\hline Daily flight bouts (n) & $\begin{array}{l}\text { Female } \\
\text { Male }\end{array}$ & $\begin{array}{c}16 \\
7\end{array}$ & $\begin{array}{l}3.86 \pm 0.65 \\
4.16 \pm 1.02\end{array}$ & $7 / 16$ & 0.207 & 0.000 & 0.750 & 1.000 \\
\hline $\begin{array}{l}\text { Flight bout duration } \\
\text { (min) }\end{array}$ & $\begin{array}{l}\text { Female } \\
\text { Male }\end{array}$ & $\begin{array}{l}16 \\
7\end{array}$ & $\begin{array}{l}63.53 \pm 19.04 \\
45.97 \pm 8.45\end{array}$ & $7 / 16$ & 0.656 & 0.178 & 0.916 & $<0.001$ \\
\hline
\end{tabular}


day of the year and significantly repeatable within individuals (Table 1). NPP and breeding performance had no effect on the foraging activity, or the number and duration of flight bouts.

\section{DISCUSSION}

During the non-breeding season, the tracked brown skuas from King George Island (Maritime Antarctic) were widely distributed over the Patagonian Shelf and shelf-break and the Argentine Basin, particularly in the area of the Brazil-Falklands Confluence. The northern end of this range is substantially further north than the distribution indicated for this species in Furness (1987), but more consistent with subsequent at-sea observations (Olmos 2002). The use by some individuals of the Southern Brazil Shelf contrasts the tracking data from brown skuas at South Georgia, which mostly spent the non-breeding season further south in the Argentine Basin (Phillips et al. 2007, Carneiro et al. 2016). Hence, the distributions of the 2 brown skua populations overlap only at the Brazil-Falklands Confluence-and indeed, there seems to be greater overlap of the birds from South Georgia with those of the closely-related Falkland skua in the area of the southern Patagonian shelf-break (Phillips et al. 2007). However, given the few Falkland skuas $(\mathrm{n}=4)$ that have been tracked and the different study periods (2002), this conclusion should be viewed with some caution.

Within the entire (population-level) non-breeding range, individuals were continuously distributed across space, suggesting a large contiguous area of suitable habitat (Fig. 1a). However, particular individuals only used distinct portions of the overall range and in a rather consistent manner within and across years (Figs. 2 \& 3). Individual consistency in migration strategies was also recorded for 17 south polar skuas Catharacta maccormicki and 3 great skuas C. skua tracked in 2 and 3 consecutive nonbreeding seasons (Kopp et al. 2011, Magnúsdóttir et al. 2012, Weimerskirch et. al. 2015), and suggests that individual consistency in migration strategies is widespread in skuas.

The 4 migration strategies identified within this brown skua population matched the seasonal shift in productivity in the wintering area. The majority of the individuals ('NorthPata' strategy) utilised the year-round, highly productive Brazil-Falklands Confluence (Garcia et al. 2004). Moreover, a small group of 3 individuals ('RioPlata' strategy) regularly switched between the highly productive region influ- enced by the outflow of Rio de la Plata (Acha et al. 2008) and the more open waters towards the Patagonian shelf-break. Individuals from the southern and northern end of the range ('SouthPata' and 'SouthBrazil' strategies) used the highly productive but seasonal frontal systems of the southern Patagonian Shelf (Acha et al. 2004, Rivas et al. 2006), and the South Brazil Shelf (Acha et al. 2004), respectively. During this period, the tracked individuals spent only a small proportion of the day flying, a pattern found in brown, great and south polar skuas (Phillips et al. 2007, Magnúsdóttir et al. 2014, Weimerskirch et al. 2015, Carneiro et al. 2016). A clear diurnal pattern was apparent, with multiple landings during the day, interspersed by 3 to 4 short flight bouts of approximately $1 \mathrm{~h}$. On average, females made longer flight bouts than males and spend less time foraging (Table 1). The sex-specific differences might be explained by the reversed sexual size dimorphism in brown skuas (Phillips et al. 2002). Males are likely to have lower wing loading, greater manoeuvrability and a lower cost of take-off, which can lead to sexspecific differences in habitat use and behaviour (Phillips et al. 2004). The level of foraging activity and number of flight bouts was not repeatable at the individual level, suggesting that brown skuas adjust their feeding behaviour depending on local food availability. However, there was a degree of individual consistency in the duration of flight bouts, which might also relate to differences between wintering regions in the distance between prey patches, or be associated with the animals' personality, since roaming behaviour and exploration is often considered as a repeatable individual trait (e.g. Dingemanse et al. 2002, Réale et al. 2007, Patrick \& Weimerskirch 2014). The lack of correlation between activity patterns and absolute NPP is most likely attributed to the coarse spatial scale, and the time lag for changes in productivity to propagate through trophic levels to affect prey abundance for higher predators such as skuas (Frederiksen et al. 2006). However, we still consider NPP values, in combination with frontal systems, to be a valuable indirect measure of large-scale food predictability and availability that can be linked to population-level distributions (see also Zainuddin et al. 2006, Pinaud \& Weimerskirch 2007, Humphries et al. 2010, Thompson et al. 2012).

Following breeding, the tracked skuas travelled to one of several alternative wintering areas within the overall range according to their particular migration strategy. In contrast, in the late non-breeding season, most tracked birds moved towards the same area around the central Patagonian shelf-break, where 
they remained for several weeks before returning to the breeding ground (Fig. 2). This area is particularly known for its strong seasonality (Signorini et al. 2006), and the increased foraging activity of the brown skuas suggests they exploit the local spring peak in primary production (Figs. $1 \& 4 \mathrm{~b}$ ). The diversity of migration strategies means that birds experience different environmental conditions during the winter, which could presumably affect body condition, laying date, breeding probability and success (e.g. Bogdanova et al. 2011, Fayet et al. 2016) and the degree of exposure to pollutants (e.g. Leat et al. 2013). The high spatial and temporal migratory connectivity (here defined as the spatial extent of one population at any given time; see Bauer et al. 2016 and Lisovski et. al 2016) shown by the tracked birds, particularly the aggregation of most individuals in the same area at the end of the winter, makes the population susceptible to oceanographic or other changes within the region.

It should be noted that 3 of the tracked skuas did not join the others on the central Patagonian shelfbreak but moved further offshore before returning to King George Island. Based on a discriminant analysis (including bill depth at the gonys, along with tarsus, culmen, wing and head length), these 3 individuals were significantly smaller than the others (authors' unpubl. data). This suggests that they might have been hybrids between brown skuas and the smaller south polar skua, as hybridisation between these closely-related species occurs frequently (Ritz et al. 2006). This might explain their distinctive migration pattern, as south polar skuas are trans-equatorial migrants (Kopp et al. 2011, Weimerskirch et al. 2015), and hybridisation is known to alter migration behaviour in other species (e.g. Helbig 1991).

Timing of migration, like distribution, differed between sexes and was consistent within individuals (Table 1). Repeatability in the arrival date at the breeding grounds was notably high, particularly given the extensive variation among individuals (within a $48 \mathrm{~d}$ range). This could reflect the varying costs and benefits of the timing of migration between individuals (Møller 1994), or among birds of different age-classes or experience levels (Jaeger et al. 2014). For example, competitive individuals can evict weak competitors from territories even if they arrive latter, and might consequently benefit from a shorter overall attendance period at the breeding grounds (Forstmeier 2002). There was some variation between years, indicating a degree of flexibility in response to local environmental conditions, as has been demonstrated across a large range of taxa (e.g. Marra et al. 1998, Gill et al. 2001, Norris et al. 2004).
As arrival date is subject to much stronger selection pressures (Both \& Visser 2001, Brown et al. 2005), we expected that individual repeatability in departure dates from King George Island would be lower. Previous studies of brown skuas, as well as other seabird species, have shown that non-breeders or failed breeders depart earlier because they are not constrained by reproductive duties (Phillips et al. 2005, 2007, Bogdanova et al. 2011, Fifield et al. 2014). However in our data there was no such relationship, although the sample size was high (18 successful and 29 unsuccessful individuals). The later departure of male brown skuas in comparison with females can be explained with their higher degree of nest-site fidelity (Parmelee \& Pietz 1987) and the benefits of a longer defence period that might increase their chance of retaining the same territory in consecutive breeding seasons.

Eight tracked individuals, most of which returned relatively early to the breeding grounds, went on a pre-laying exodus of ca. 1000 to $1500 \mathrm{~km}$ back to their non-breeding ranges. The majority of brown skuas tracked from South Georgia, particularly females, also went on a pre-laying exodus (Phillips et al. 2007, Carneiro et al. 2016). There are obvious benefits of early arrival; brown skuas are highly territorial and their reproductive success depends on the quality of the acquired territory (Hahn \& Bauer 2008). However, there might also be costs, such as the increased risk of encountering adverse weather during the early season (Møller 1994). It appears that a pre-laying exodus is discretionary, presumably depending on conditions at the breeding colony, as only 1 of the 5 individuals tracked in multiple years performed such a trip twice.

In conclusion, we recorded highly consistent individual migration strategies in brown skuas from King George Island; this reflected considerable variation in timing of migration, non-breeding distributions and activity patterns. The tracked birds differed extensively in their arrival dates at the breeding ground, a migratory trait that is supposed to be under strong selection (e.g. Kokko 1999), whereas the arrival dates within individuals were highly repeatable. Based on the high levels of primary production, the tracked brown skuas mainly exploit one of a number of alternative wintering areas within the overall non-breeding range. However, almost all individuals moved to take advantage of a seasonal peak in marine productivity in a particular area for several weeks before the final return to the colony; these birds are presumably returning to this area of high resource abundance that they 
experienced during an initial early-life explorationrefinement phase (Guilford et al. 2011). The 3 individuals that showed a different late-winter distribution may not have visited this otherwise common area in previous years, or may be hybrids exhibiting an alternative migration strategy that reflects genetic differences. We were unable to disentangle the relative contribution of genetic control versus past experience in determining individual migration strategies. To this end, we would need to track movements of juvenile brown skuas during their first years at sea, and ideally, also track their parents. Such data would also be extremely valuable for determining the flexibility in migration strategies within and across generations, and provide an indication of how quickly seabirds can adapt to rapid changes in the environment.

Acknowledgements. We thank the following former members of the Polar \& Bird Ecology Group for their instrumental help in the field and/or lab: Markus Ritz, Anja Ruß, Anne Fröhlich, Christina Braun, Tobias Gütter, Michel Stelter and Jan Esefeld, and 3 anonymous referees for helpful comments on the manuscript. The research was supported by the Deutsche Forschungsgemeinschaft (PE 454/1 ff.), and the German Federal Environment Agency (FKZ 370891 102, $370891102 \& 371287$ 100), which also approved the field work (I 2.4 - 94003-3/151).

\section{LITERATURE CITED}

Acha EM, Mianzan HW, Guerrero RA, Favero M, Bava J (2004) Marine fronts at the continental shelves of austral South America: physical and ecological processes. J Mar Syst 44:83-105

Acha EM, Mianzan HW, Guerrero RA, Carreto J, Giberto D, Montoya N, Carignan M (2008) An overview of physical and ecological processes in the Rio de la Plata Estuary. Cont Shelf Res 28:1579-1588

Ådahl E, Lundberg PER, Jonzén N (2006) From climate change to population change: the need to consider annual life cycles. Glob Change Biol 12:1627-1633

Bates D, Mächler M, Bolker B, Walker S (2014) Fitting linear mixed-effects models using lme4. J Stat Softw 67:1-48

Bauer S, Lisovski S, Hahn S (2016) Timing is crucial for consequences of migratory connectivity. Oikos 125:605-612

Berthold P (2001) Bird migration: a general survey, $2^{\text {nd }}$ edn. Oxford University Press, Oxford

Bogdanova MI, Daunt F, Newell M, Phillips RA, Harris MP, Wanless S (2011) Seasonal interactions in the blacklegged kittiwake, Rissa tridactyla: links between breeding performance and winter distribution. Proc R Soc B 278:2412-2418

Both C, Visser ME (2001) Adjustment to climate change is constrained by arrival date in a long-distance migrant bird. Nature 411:296-298

Bridge ES, Thorup K, Bowlin MS, Chilson PB and others (2011) Technology on the move: recent and forthcoming innovations for tracking migratory birds. Bioscience 61: 689-698
Brown CR, Brown MB, Raouf SA, Smith LC, Wingfield JC (2005) Effects of endogenous steroid hormone levels on annual survival in cliff swallows. Ecology 86: 1034-1046

Carneiro APB, Manica A, Clay TA, Silk JRD, King M, Phillips RA (2016) Consistency in migration strategies and habitat preferences of brown skuas over two winters, a decade apart. Mar Ecol Prog Ser 553:267-281

* Cherel Y, Quillfeldt P, Delord K, Weimerskirch H (2016) Combination of at-sea activity, geolocation and feather stable isotopes documents where and when seabirds moult. Front Ecol Evol 4:3

WDias MP, Granadeiro JP, Phillips RA, Alonso H, Catry P (2011) Breaking the routine: individual Cory's shearwaters shift winter destinations between hemispheres and across ocean basins. Proc R Soc B 278:1786-1793

* Dingemanse NJ, Both C, Drent PJ, van Oers K, van Noordwijk AJ (2002) Repeatability and heritability of exploratory behaviour in great tits from the wild. Anim Behav 64:929-938

Fayet AL Freeman R, Shoji A, Boyle D and others (2016) Drivers and fitness consequences of dispersive migration in a pelagic seabird. Behav Ecol 27:1061-1072

Fifield DA, Montevecchi WA, Garthe S, Robertson GJ, Kubetzki U, Rail JF (2014) Migratory tactics and wintering areas of northern gannets (Morus bassanus) breeding in North America. Ornithol Monogr 79:1-63

* Forstmeier W (2002) Benefits of early arrival at breeding grounds vary between males. J Anim Ecol 71:1-9

* Frederiksen M, Edwards M, Richardson AJ, Halliday NC, Wanless S (2006) From plankton to top predators: bottom-up control of a marine food web across four trophic levels. J Anim Ecol 75:1259-1268

Fridolfsson AK, Ellegren H (1999) A simple and universal method for molecular sexing of non-ratite birds. J Avian Biol 30:116-121

Furness RW (1987) The skuas, $1^{\text {st }}$ edn. T \& AD Poyser, Calton * Garcia CA, Sarma Y, Mata MM, Garcia VM (2004) Chlorophyll variability and eddies in the Brazil-Malvinas Confluence region. Deep-Sea Res II 51:159-172

Fill JA, Norris K, Potts PM, Gunnarsson TG, Atkinson PW, Sutherland WJ (2001) The buffer effect and large-scale population regulation in migratory birds. Nature 412: 436-438

*Guilford T, Freeman R, Boyle D, Dean B, Kirk H, Phillips RA, Perrins C (2011) A dispersive migration in the Atlantic puffin and its implications for migratory navigation. PLOS ONE 6:e21336

Hahn S, Bauer S (2008) Dominance in feeding territories relates to foraging success and offspring growth in brown skuas Catharacta antarctica lonnbergi. Behav Ecol Sociobiol 62:1149-1157

*Harrison XA, Blount JD, Inger R, Norris DR, Bearhop S (2011) Carry-over effects as drivers of fitness differences in animals. J Anim Ecol 80:4-18

*Helbig AJ (1991) Inheritance of migratory direction in a bird species: a cross-breeding experiment with SE-and SWmigrating blackcaps (Sylvia atricapilla). Behav Ecol Sociobiol 28:9-12

*Humphries NE, Queiroz N, Dyer JRM, Pade NG and others (2010) Environmental context explains Lévy and Brownian movement patterns of marine predators. Nature 465: 1066-1069

Jaeger A, Goutte A, Lecomte VJ, Richard P and others (2014) Age, sex, and breeding status shape a complex 
foraging pattern in an extremely long-lived seabird. Ecology 95:2324-2333

KKarnovsky NJ, Kwaśniewski S, Marcin Węsławski J, Walkusz W, Beszczyńska-Möller A (2003) Foraging behavior of little auks in a heterogeneous environment. Mar Ecol Prog Ser 253:289-303

Kokko H (1999) Competition for early arrival in migratory birds. J Anim Ecol 68:940-950

Kopp M, Peter HU, Mustafa O, Lisovski S, Ritz MS, Phillips RA, Hahn S (2011) South polar skuas from a single breeding population overwinter in different oceans though show similar migration patterns. Mar Ecol Prog Ser 435:263-267

Kuznetsova A, Brockhoff PB, Christensen RHB (2015) lmerTest: tests in linear mixed effects models. R package version 2.0-29. https://CRAN.R-project.org/package $=$ lmerTest

Leat EHK, Bourgeon S, Magnusdottir E, Gabrielsen GW and others (2013) Influence of wintering area on persistent organic pollutants in a breeding migratory seabird. Mar Ecol Prog Ser 491:277-293

* Lessells C, Boag PT (1987) Unrepeatable repeatabilities: a common mistake. Auk 104:116-121

Lisovski S, Hewson CM, Klaassen RH, Korner-Nievergelt F, Kristensen MW, Hahn S (2012) Geolocation by light: accuracy and precision affected by environmental factors. Methods Ecol Evol 3:603-612

Lisovski S, Gosbell K, Christie M, Hoye BJ and others (2016) Movement patterns of sanderling (Calidris alba) in the East Asian-Australasian flyway and a comparison of methods for identification of crucial areas for conservation. Emu 116:168-177

*Magnúsdóttir E, Leat EH, Bourgeon S, Strøm H and others (2012) Wintering areas of great skuas Stercorarius skua breeding in Scotland, Iceland and Norway. Bird Study 59:1-9

* Magnúsdóttir E, Leat EH, Bourgeon S, Jónsson JE and others (2014) Activity patterns of wintering great skuas Stercorarius skua. Bird Study 61:301-308

* Marra PP, Hobson KA, Holmes RT (1998) Linking winter and summer events in a migratory bird by using stable-carbon isotopes. Science 282:1884-1886

Mattern T, Masello JF, Ellenberg U, Quillfeldt P (2015) Actave.net - a web-based tool for the analysis of seabird activity patterns from saltwater immersion geolocators. Methods Ecol Evol 6:859-864

McFarlane Tranquilla LA, Montevecchi WA, Fifield DA, Hedd A, Gaston AJ, Robertson GJ, Phillips RA (2014) Individual winter movement strategies in two species of murre (Uria spp.) in the northwest Atlantic. PLOS ONE 9: e90583

McKnight A, Irons DB, Allyn AJ, Sullivan KM, Suryan RM (2011) Winter dispersal and activity patterns of postbreeding black-legged kittiwakes Rissa tridactyla from Prince William Sound, Alaska. Mar Ecol Prog Ser 442: 241-253

Møller AP (1994) Phenotype-dependent arrival time and its consequences in a migratory bird. Behav Ecol Sociobiol 35:115-122

* Mueller T, O'Hara RB, Converse SJ, Urbanek RP, Fagan WF (2013) Social learning of migratory performance. Science 341:999-1002

Müller MS, Massa B, Phillips RA, Dell'Omo G (2014) Individual consistency and sex differences in migration strategies of Scopoli's shearwaters Calonectris diomedea despite year differences. Curr Zool 60: 631-641

Nakagawa S, Schielzeth H (2010) Repeatability for Gaussian and non-Gaussian data: a practical guide for biologists. Biol Rev Camb Philos Soc 85:935-956

Norris DR, Marra PP, Kyser TK, Sherry TW, Ratcliffe LM (2004) Tropical winter habitat limits reproductive success on the temperate breeding grounds in a migratory bird. Proc R Soc B 271:59-64

Oksanen J, Blanchet FG, Kindt R, Legendre P and others (2015) vegan: community ecology package. R package version 2.3-1. https://cran.r-project.org/web/packages/ vegan/index.html

Olmos F (2002) Non-breeding seabirds in Brazil: a review of band recoveries. Ararajuba 10:31-42

O Orsi AH, Whitworth T, Nowlin WD (1995) On the meridional extent and fronts of the Antarctic Circumpolar Current. Deep-Sea Res I 42:641-673

* Parmelee DF, Pietz PJ (1987) Philopatry, mate and nest-site fidelity in the brown skuas of Anvers Island, Antarctica. Condor 89:916-919

* Patrick SC, Weimerskirch H (2014) Personality, foraging and fitness consequences in a long lived seabird. PLOS ONE 9:e87269

* Phillips RA, Dawson DA, Ross DJ (2002) Mating patterns and reversed size dimorphism in southern skuas (Stercorarius skua lonnbergi). Auk 119:858-863

* Phillips RA, Silk JRD, Phalan B, Catry P, Croxall JP (2004) Seasonal sexual segregation in two Thalassarche albatross species: Competitive exclusion, reproductive role specialization or foraging niche divergence? Proc R Soc B 271:1283-1291

*Phillips RA, Silk JRD, Croxall JP, Afanasyev V, Bennett VJ (2005) Summer distribution and migration of nonbreeding albatrosses: individual consistencies and implications for conservation. Ecology 86:2386-2396

*Phillips RA, Catry P, Silk JRD, Bearhop S, McGill R, Afanasyev V, Strange IJ (2007) Movements, winter distribution and activity patterns of Falkland and brown skuas: insights from loggers and isotopes. Mar Ecol Prog Ser 345:281-291

* Pinaud D, Weimerskirch H (2007) At-sea distribution and scale-dependent foraging behaviour of petrels and albatrosses: a comparative study. J Anim Ecol 76:9-19

* Quillfeldt P, Voigt CC, Masello JF (2010) Plasticity versus repeatability in seabird migratory behaviour. Behav Ecol Sociobiol 64:1157-1164

R Core Team (2015) R: a language and environment for statistical computing. R Foundation for Statistical Computing, Vienna

Kéale D, Reader SM, Sol D, McDougall PT, Dingemanse NJ (2007) Integrating animal temperament within ecology and evolution. Biol Rev Camb Philos Soc 82:291-318

Ritz MS, Hahn S, Janicke T, Peter HU (2006) Hybridisation between south polar skua (Catharacta maccormicki) and brown skua (C. antarctica lonnbergi) in the Antarctic Peninsula region. Polar Biol 29:153-159

* Ritz MS, Millar C, Miller GD, Phillips RA and others (2008) Phylogeography of the southern skua complex-rapid colonization of the southern hemisphere during a glacial period and reticulate evolution. Mol Phylogenet Evol 49: 292-303

Rivas AL, Dogliotti AI, Gagliardini DA (2006) Seasonal variability in satellite-measured surface chlorophyll in the Patagonian Shelf. Cont Shelf Res 26:703-720 
Shealer DA (2002) Foraging behavior and food of seabirds. In: Shreiber EA, Burger J (eds) Biology of marine birds. CRC Press, Boca Raton, FL, p 137-177

Signorini SR, Garcia VMT, Piola AR, Garcia CAE, Mata MM, McClain CR (2006) Seasonal and interannual variability of calcite in the vicinity of the Patagonian shelf break $\left(38^{\circ} \mathrm{S}-52^{\circ} \mathrm{S}\right)$. Geophys Res Lett 33:L16610

Small-Lorenz SL, Culp LA, Ryder TB, Will TC, Marra PP (2013) A blind spot in climate change vulnerability assessments. Nat Clim Change 3:91-93

Spalding MD, Fox HE, Allen GR, Davidson N and others (2007) Marine ecoregions of the world: a bioregionalization of coastal and shelf areas. Bioscience 57:573-583

Sumner MD, Wotherspoon SJ, Hindell MA (2009) Bayesian estimation of animal movement from archival and satellite tags. PLOS ONE 4:e7324

Thompson SA, Sydeman WJ, Santora JA, Black BA and others (2012) Linking predators to seasonality of upwelling: using food web indicators and path analysis

Editorial responsibility: Jacob González-Solís (Guest Editor), Barcelona, Spain to infer trophic connections. Prog Oceanogr 101:106-120 *Weimerskirch H (2007) Are seabirds foraging for unpredictable resources? Deep-Sea Res II 54:211-223

*Weimerskirch H, Tarroux A, Chastel O, Delord K, Cherel Y, Descamps S (2015) Population-specific wintering distributions of adult south polar skuas over three oceans. Mar Ecol Prog Ser 538:229-237

Wotherspoon SJ, Sumner MD, Lisovski S (2013a) R package BAStag: basic data processing for light based geolocation archival tags. GitHub Repository. https://github. com/SWotherspoon/BAStag

Wotherspoon SJ, Sumner MD, Lisovski S (2013b) R package SGAT: solar/satellite geolocation for animal tracking. GitHub Repository. http://github.com/swotherspoon/sgat

Zainuddin M, Kiyofuji H, Saitoh K, Saitoh SI (2006) Using multi-sensor satellite remote sensing and catch data to detect ocean hot spots for albacore (Thunnus alalunga) in the northwestern North Pacific. Deep-Sea Res II 53: 419-431

Submitted: May 10, 2016; Accepted: October 12, 2016 Proofs received from author(s): November 27, 2016 